\title{
PEMERIKSAAN GULA DARAH, KOLESTROL, TEKANAN \\ DARAH DAN ASAM URAT GRATIS DI CAR FREE DAY SIMPANG LIMA GUMUL KABUPATEN KEDIRI
}

\author{
M iftakhul M u'alimah'), Anis Nikmatul Nikmah'), Dina Dewi Anggraini3), Erike \\ Yunicha Viridula ${ }^{4}$, Galuh Pradian Yanuaringsih ${ }^{5}$, Lindha Sri Kusumawati6), \\ Putri Wahyu Wigati ${ }^{7)}$, Rahma Kusuma Dewi ${ }^{8)}$, Weni Tri Purnani ${ }^{9}$ ) \\ Fakultas Ilmu Kesehatan, Universitas Kadiri \\ miftakhulmualimah@unik-kediri.ac.id ${ }^{1)}$, anisnikmatul@unik-kediri.ac.id ${ }^{2)}$ \\ dinadewi@unik-kediri.ac.id ${ }^{3)}$ erikey@unik-kediri.ac.id ${ }^{4)}$, galuhpradian@unik-

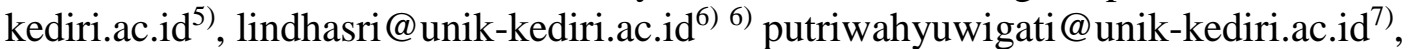 \\ rahmakusumadewi@unik-kediri.ac.id ${ }^{8)}$ wenitripurnani@unik-kediri.ac.id ${ }^{9)}$
}

\begin{abstract}
ABSTRAK
Diabetes mellitus, kolestrol, asam urat dan tekanan darah tinggi atau hipertensi bukanlah penyakit yang ringan, adanya penyakit ini akan membawa dampak besar bagi penderitanya apabila tidak dicegah atau ditangani dengan benar. Tujuan dari diadakannya kegiatan pengabdian masyarakat ini adalah untuk membantu memberikan fasilitas kepada masyarakat agar dapat mendapatkan pelayanan pemeriksaan secara gratis, diharapkan masyarakat mampu termotivasi untuk melakukan pencegahan dan penanganan secara dini terhadap penyakit-penyakit tersebut. Metode yang digunakan yaitu melakukan pendekatan terhadap mitra, mengidentifikasi masalah, melakukan kegiatan pengabmas dan hasil yang didapatkan akan dilaporkan kepihak mitra untuk digunakan wacana dan evaluasi. Hasil kegiatan yang didapatkan belum sepenuhnya memenuhi target, untuk itu pelaksana melengkapi kegiatan dengan memberikan penyuluhan-penyuluhan serta KIE kepada klien yang hadir agar klien yang datang tetap mendapatkan manfaat dengan diadakannya kegiatan ini.

Kata kunci : Diabetes mellitus, kolestrol, asam urat, tekanan darah tinggi, hipertensi, pemeriksaan gratis

\section{PENDAHULUAN}

Diabetes mellitus merupakan suatu penyakit yang ditandai oleh kadar glukosa darah melebihi normal dan gangguan metabolisme karbohidrat, lemak dan protein yang disebabkan kekurangan hormon insulin secara relatif maupun absolut. Bila hal ini dibiarkan tak terkendali dapat terjadi komplikasi metabolik akut maupun komplikasi vaskuler jangka panjang, baik mikroangiopati maupun makroangiopati (Darmono
\end{abstract}


2007). Diabetes mellitus perlu diwaspadai karena sifat penyakit yang kronik progresif, jumlah penderita semakin meningkat dan banyak dampak negatif yang ditimbulkan.

Diabetes Mellitus (DM) merupakan salah satu masalah kesehatan yang berdampak pada produktivitas dan dapat menurunkan sumber daya manusia. Penyakit ini tidak hanya berpengaruh secara individu, tetapi sistem kesehatan suatu negara (Suyono, 2002). Dampak negatif yang ditimbulkan dari DM cukup besar antara lain, komplikasi kronik pada penyakit jantung kronis, hipertensi, otak, sistem saraf, hati, mata dan ginjal. Diabetes sendiri merupakan penyakit yang disebakan oleh tingginya kadar gula darah akibat gangguan pada pankreas dan insulin. Di Indonesia, data Riskesdas menunjukkan bahwa terjadi peningkatan prevalensi Diabetes di Indonesia dari 5,7\% tahun 2007 menjadi 6,9\% atau sekitar sekitar 9,1 juta pada tahun 2013. Data International Diabetes Federation tahun 2015 menyatakan jumlah estimasi penyandang Diabetes di Indonesia diperkirakan sebesar 10 juta (Kemenkes RI, 2016)

Kolesterol adalah suatu molekul lemak di dalam sel dibagi menjadi LDL, HDL, total kolesterol dan trigliserida. Kolesterol sebenarnya merupakan salah satu komponen lemak. Seperti kita ketahui, lemak merupakan salah satu zat gizi yang sangat diperlukan oleh tubuh kita disamping zat gizi lain seperti karbohidrat, protein, vitamin dan mineral. Lemak merupakan salah satu sumber energi yang memberikan kalori paling tinggi tetapi bila di dalam tubuh kita terdapat kadar kolestrol yang tinggi dapat menimbulkan resiko tinggi (Mahatidanar, 2015). Penumpukan lemak di dinding arteri dapat menyebabkan hipertensi atau yang lebih dikenal dengan tekanan darah tinggi. Sampai saat ini, hipertensi masih merupakan tantangan besar di Indonesia. Betapa tidak, hipertensi merupakan kondisi yang sering ditemukan pada pelayanan kesehatan primer kesehatan. Hal itu merupakan masalah kesehatan dengan prevalensi yang tinggi, yaitu sebesar 25,8\%, sesuai dengan data Riskesdas 2013. Di samping itu, pengontrolan hipertensi belum adekuat meskipun obat-obatan yang efektif banyak tersedia (Kemenkes RI, 2014).

Penyakit asam urat adalah suatu keadaan dimana terjadi peningkatan kadar asam urat dalam darah diatas normal. Keadaan ini dapat terjadi karena peningkatan metabolisme asam urat sehingga terjadi peningkatan produksi asam urat. Adanya 
gangguan pengeluaran asam urat oleh ginjal juga mengakibatkan peningkatan kadar asam urat dalam darah. Kadar yang tinggi dalam darah bila dibiarkan, lama-kelamaan akan mengendap dalam bentuk kristal pada sendi dan jaringan lunak. Kristal tersebut dapat menumpuk dan menimbulkan peradangan akut dan nyeri (Somahita, 2016)

Keempat faktor tadi dapat menyebabkan berbagai penyakit berbahaya, seperti diabetes, penyakit jantung, stroke dan lainnya. Data Sample Registration Survey tahun 2014 menunjukkan bahwa ada 3 penyebab kematian terbesar di Indonesia adalah stroke $(21,1 \%)$, penyakit jantung koroner (12,9\%) dan diabetes (6,7\%), apabila kondisi ini tidak segera diatasi dapat menyebabkan penurunan produktivitas, disabilitias bahkan kematian dini. (Kemenkes RI, 2016).

Dengan adanya latar belakang tersebut, kami tertarik untuk melakukan kegiatan pengabdian masyarakat berupa pemeriksaan kadar gula darah, kolestrol dan asam urat gratis. Diharapkan dengan diadakan kegiatan ini warga yang datang untuk melakukan pemeriksaan dapat mengetahui kondisi kesehatannya secara dini, sehingga dapat dilakukan tindakan pengobatan segera apabila didapatkan ketidaknormalan.

\section{METODE PELAKSANAAN}

Dalam rangka untuk mengatasi permasalahan yang dihadapi mitra, yaitu masih tingginya angka kejadian diabetes melitus, kolestrol, hipertensi dan asam urat di Kabupaten Kediri, metode pelaksanaan yang dilakukan adalah memberikan pelayanan pemeriksaan gratis meliputi gula darah, kolestrol, tekanan darah dan asam urat.

Selama pelaksanaan pengabdian masyarakat ini, mitra akan menyediakan sumber daya manusia (SDM) dan melakukan pendampingan pada saat kegiatan berlangsung, dalam hal ini dilakukan oleh perwakilan dari dinas kesehatan Kabupaten Kediri.

Prosedur kerja yang kita lakukan kami gambarkan dalam bentuk bagan sebagai berikut : 


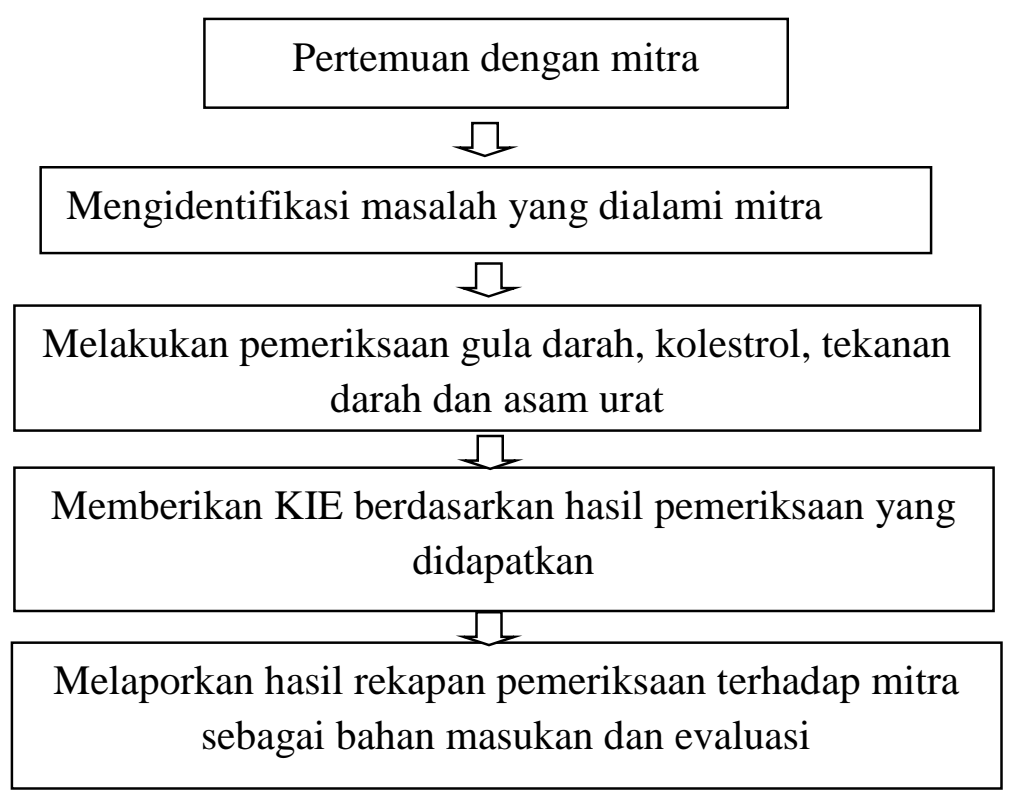

\section{HASIL DAN PEMBAHASAN}

\section{Judul Kegiatan}

Pemeriksaan gula darah, kolestrol, tekanan darah dan asam urat gratis di car free day Simpang Lima Gumul Kabupaten Kediri”

\section{Waktu, Tempat Pelaksanaan, Peserta}

Waktu : Kegiatan pengabdian masyarakat dilakukan setiap hari minggu mulai pukul 06.00 - 10.00 WIB selama bulan Desember 2017 (empat minggu)

Tempat : car free day Simpang Lima Gumul Kabupaten Kediri

Peserta : petugas yang bertanggung jawab dalam kegiatan pengabdian masyarakat ditiap minggunya tercantum dalam tabel 1 , sebagai berikut : 
Tabel 1. Data Pelaksana Pengabmas Tiap Minggu

\begin{tabular}{|c|c|c|}
\hline $\begin{array}{r}\text { Minggu } \\
\mathrm{Ke}-\end{array}$ & Tanggal & Dosen Yang Bertugas \\
\hline 1 & 3 Des 2017 & $\begin{array}{l}\text { 1. Anis Nikmatul Nikmah, SST., M.Kes*) } \\
\text { 2. Galuh Pradian Y., SST., M.Kes }\end{array}$ \\
\hline 2 & 10 Des 2017 & $\begin{array}{l}\text { 1. Dina Dewi Anggraini, S.S.T.Keb., M.Kes*) } \\
\text { 2. Erike Yunicha V., SST., M.PH }\end{array}$ \\
\hline 3 & 17 Des 2017 & $\begin{array}{l}\text { 1. Miftahul Mu'alimah, SST., M.Kes*) } \\
\text { 2. Lindha Sri K, SST., M.PH } \\
\text { 3. Putri Wahyu W., SST., M.PH }\end{array}$ \\
\hline 4 & 24 Des 2017 & $\begin{array}{l}\text { 1. Rahma Kusuma Dewi, ST., S.ST., M.PH } \\
\text { 2. Weni Tri Purnani, S.ST., M.Kes. }\end{array}$ \\
\hline
\end{tabular}

Keterangan : Penanggung Jawab Kelompok

\section{Sasaran/Target Kegiatan}

Sasaran kegiatan pengabdian masyarakat ini adalah seluruh pengunjung dewasa dan lansia yang bersedia datang ke stand untuk di lakukan pemeriksaan.

\section{Pelaksanaan Kegiatan Pemeriksaan}

Lembaga Penelitian dan Pengabdian kepada Masyarakat (LPPM) Fakultas Ilmu Kesehatan Universitas Kadiri dalam melaksanakan semua gerak dan langkah didukung oleh berbagai sumber daya dari berbagai jurusan sesuai dengan program yang ditawarkan. Kegiatan pengabdian berupa pemeriksaan gratis ini dilaksanakan oleh tim dosen dari program studi Kebidanan DIV Fakultas Ilmu Kesehatan Universitas Kadiri yang dibantu oleh 5-10 orang mahasiswa pada tiang minggunya. Kegiatan pengabdian masyarakat ini mencapai keberhasilan karena dukungan berbagai pihak yang terkait dan mau bekerjasama dengan baik, yaitu :

1. Dinas Kesehatan Kabupaten Kediri (Mitra Utama)

2. Dinas Perhubungan Kabupaten Kediri

3. Dinas Pariwisata Kabupaten Kediri 
Hasil dari kegiatan pemeriksaan yang dilakukan, dapat dijadikan masukan dan bahan evaluasi untuk ditindaklanjuti oleh pihak mitra.

\section{Hasil Pemeriksaan}

Hasil dari pemeriksaan gratis ini dapat dilihat dari tabel 2 dan lampiran dokumentasi sebagai berikut :

Tabel 2. Rekap Jumlah Pengunjung

\begin{tabular}{ccccccccc}
\hline & & \multicolumn{6}{c}{ JUMLAH PENGUNJUNG } \\
\cline { 3 - 9 } NO & TANGGAL & \multicolumn{2}{c}{ Berdasarkan } & \multicolumn{3}{c}{ Berdasarkan Jenis Pemeriksaan } \\
& KEGIATAN & \multicolumn{2}{c}{ Jenis Kelamin } & \multicolumn{5}{c}{ Yang Diberikan } \\
\cline { 3 - 9 } & & L & P & $\Sigma$ & TD & $\begin{array}{c}\text { Gula } \\
\text { darah }\end{array}$ & Kolestrol & $\begin{array}{c}\text { Asam } \\
\text { Urat }\end{array}$ \\
\hline 1 & 03 Des 2017 & 25 & 13 & 159 & 159 & - & 7 & 21 \\
\hline 2 & 10 Des 2017 & 5 & 21 & 26 & 26 & - & - & 23 \\
\hline 3 & 17 Des2017 & 13 & 18 & 31 & 31 & - & 9 & 18 \\
\hline 4 & 24 Des 2017 & 2 & 17 & 19 & 19 & 13 & 1 & 8 \\
\hline & JUMLAH & 45 & 190 & 235 & 235 & 13 & 17 & 70
\end{tabular}

Pada pemeriksaan ini dapat dilihat bahwa hasil pemeriksaan masih sangat jauh dari target yang diinginkan, peserta yang mendapatkan pemeriksaan gula darah, kolesterol dan asam urat masih sangat sedikit. Adapun beberapa kendala yang dihadapi pada saat pelaksanaan antara lain :

1.Langkanya stik pemeriksaan untuk jenis alat yang kami miliki. Sehingga pemeriksaan yang kita lakukan tidak dapat berjalan masksimal dan tidak semua peserta yang mengunjungi stan kami mendapatkan semua pemeriksaan yang disediakan.

2. Waktu kegiatan pengabmas terbatas, karena diberlakukannya car free day juga dibatasi sampai pada jam tertentu.

Dengan adanya kondisi jumlah pengunjung dan jumlah pemeriksaan yang dapat kita lakukan yang belum dapat mencapai target, kita mengisi kekurangan kegiatan yang dilakukan dengan memperbanyak penyuluhan dan KIE pada pengunjung yang hadir, 
dengan harapan pengunjung yang hadir tidak kecewa karena tidak dapat melakukan pemeriksaan yang mereka harapkan.

\section{DAFTAR PUSTAKA}

Darmono. (2007). Diabetes Melitus Ditinjau dari Berbagai Aspek Penyakit Dalam. Semarang: CV Agung Semarang

Mahatidanar, Andika. 2015. Manfaat Buah Apel (Malus domestica) untuk Pencegahan Stroke pada Pasien Kolestrol Tinggi. J Agromed Unila | Volume 2 | Nomor 3 | Agustus 2015

Somahita, Titi. 2016. Bengkak Sendi Karena Asam Urat. Avaliable at : http://pantiwilasa.com/majalahkasih/detailpost/bengkak-sendikarena-asam-urat. Diakses tanggal 17 November 2017

Suyono, S., 2002, Patofisiologi Diabetes Mellitus, cetakan ke 2, Fakultas Kedokteran Universitas Indonesia, Jakarta, pp. 7-15.

. 2016. Menkes: Mari Kita Cegah Diabetes Dengan Cerdik. Avaliable at: http://www.depkes.go.id/article/print/16040700002/menkes-mari-kita-cegahdiabetes-dengan-cerdik.html. diakses tanggal 17 November 2017

RI

2014. Hipertensi. Jakarta: Pusat Data dan Informasi Kementrian Kesehatan 


\section{LAMPIRAN}

Foto-foto Kegiatan Pengabdian Masyarakat

a. Minggu I, tanggal 3 Desember 2017

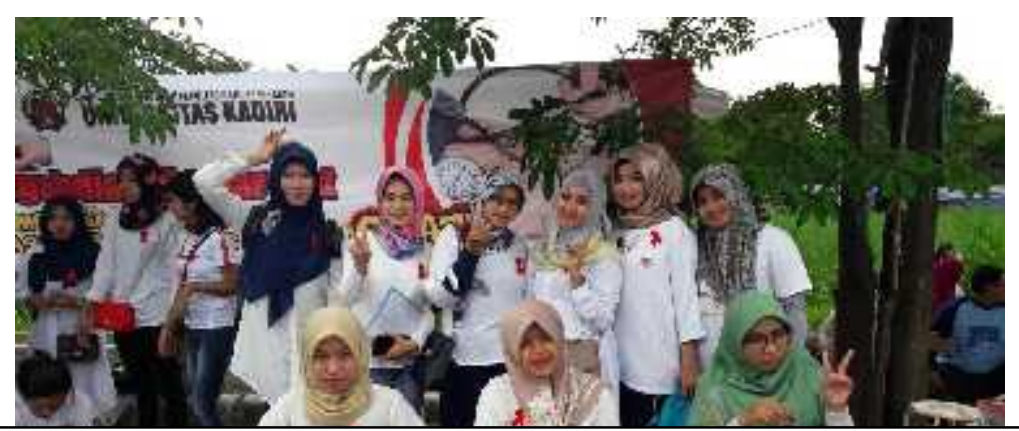

Foto Dosen Bersama Mahasiswa yang Melaksanakan Pengabmas

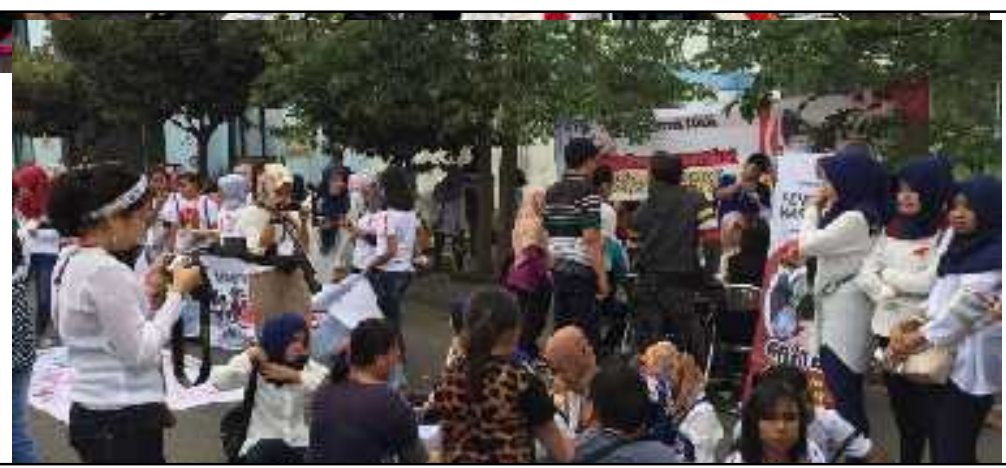

Pengunjung Car Free Day yang Datang Untuk Mendapatkan Pemeriksaan Gratis 


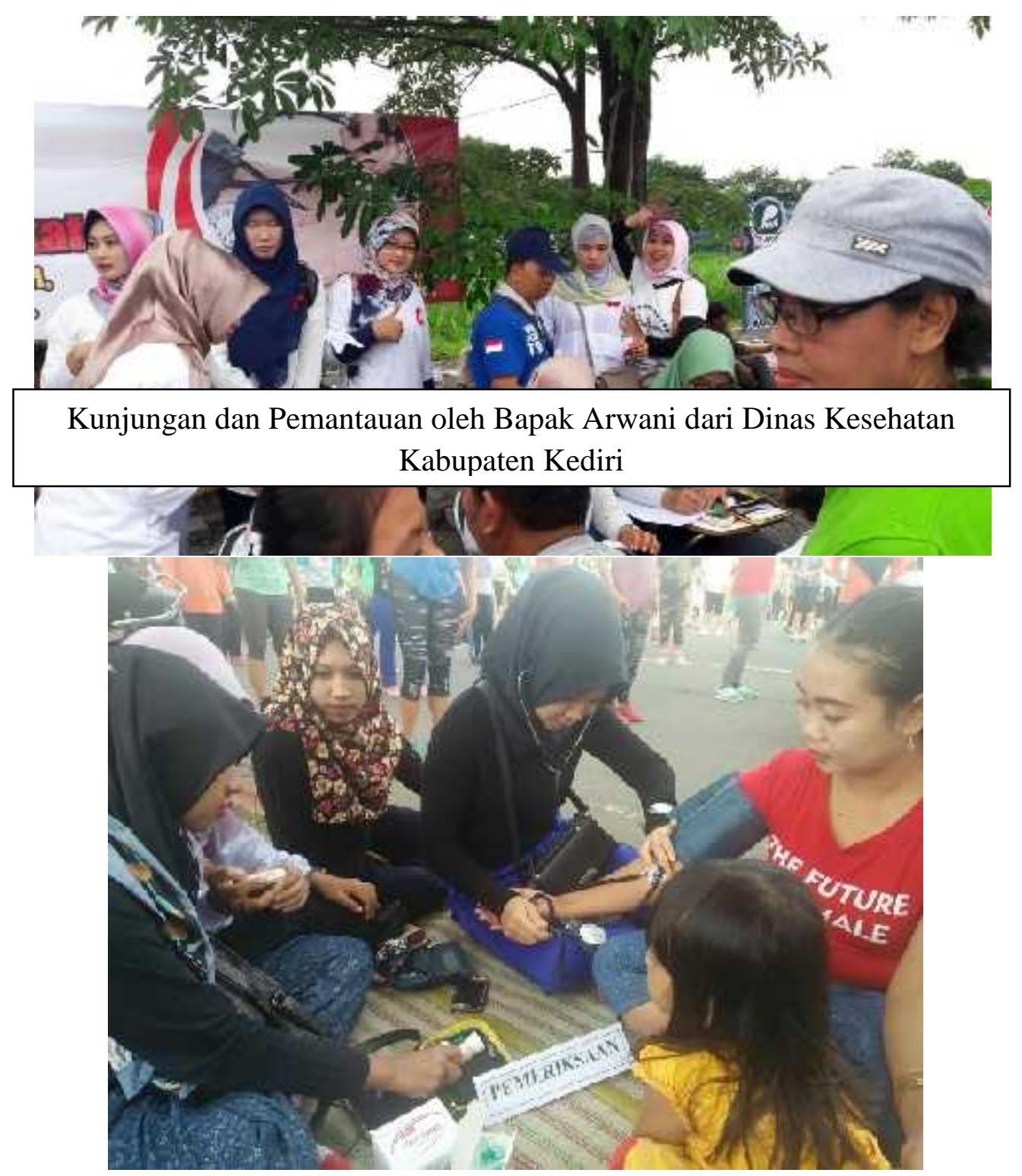

b. Minggu II, 10 Desember 2017

Pemeriksaan Pengunjung Car Free Day Oleh Mahasiswa 
c. Minggu III, 17 Desember 2017

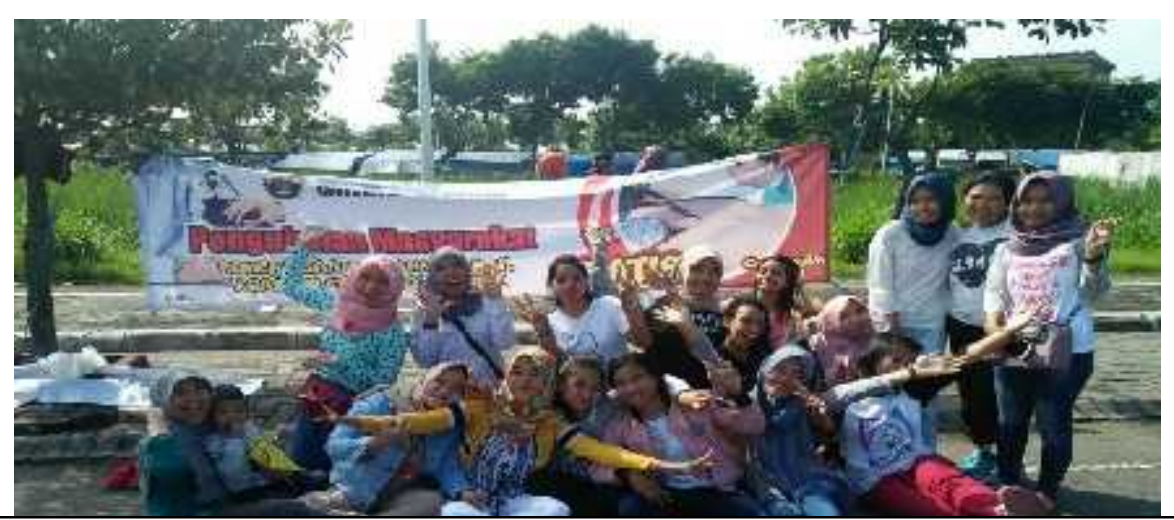

Foto Dosen Bersama Mahasiswa yang Melaksanakan Pengabmas

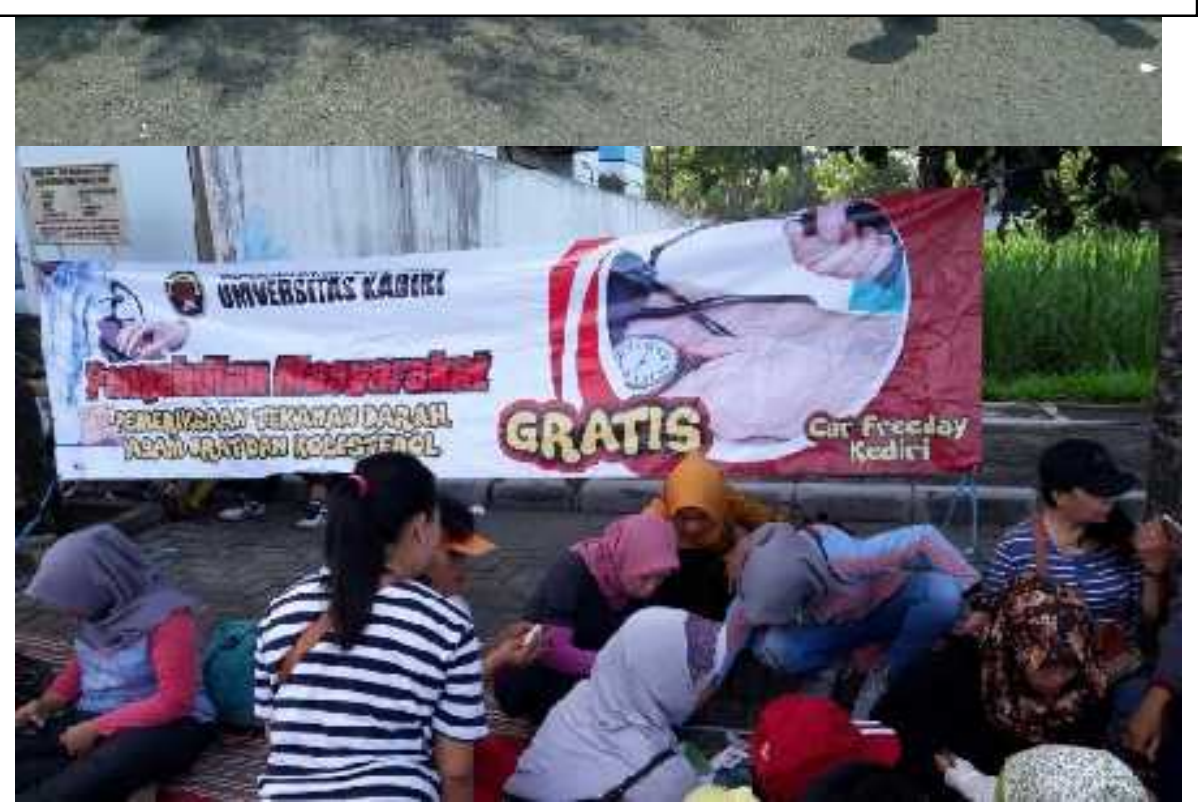

d. Minggu IV, 24 Desember 2017 


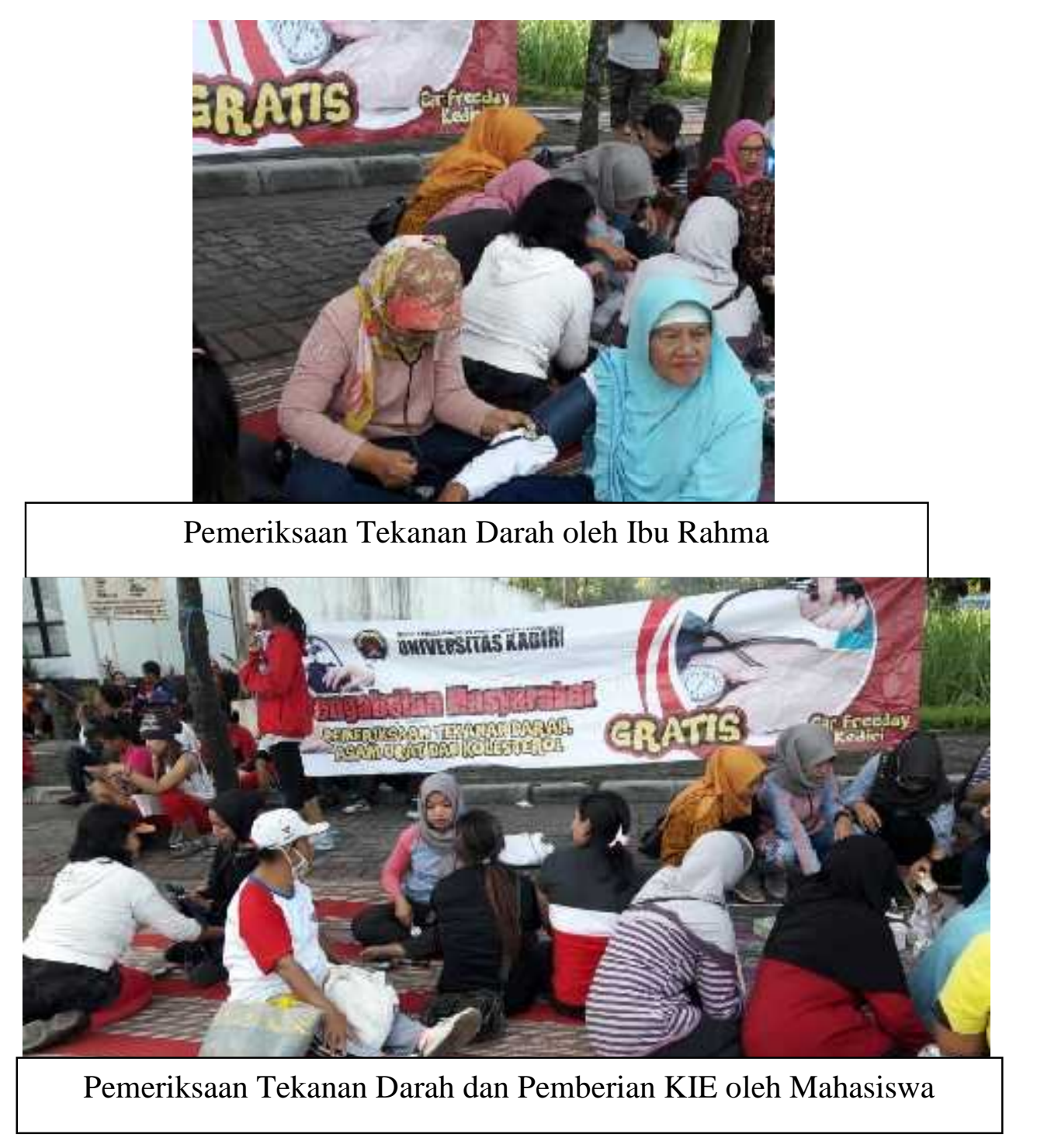

